УДК 631.8:581.1

ОЦЕНКА ЭФФЕКТИВНОСТИ ОБРАБОТКИ СЕМЯН КАПУСТНЫХ

КУЛЬТУР АССОЦИАТИВНЫМИ РИЗОБАКТЕРИЯМИ В УСЛОВИЯХ НОРМАЛЬНОГО УВЛАЖНЕНИЯ И ПОЧВЕННОЙ ЗАСУХИ

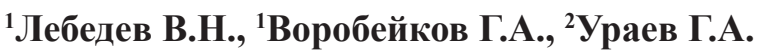

${ }^{1}$ ФББОУ ВО «Российский государственный педагогический университет им. А.И. Гериена», Санкт-Петербург, е-mail: antares-80@yandex.ru; ${ }^{2}$ ФББОУ ВО «Петербургский государственный университет путей сообщения Императора Александра I», Санкт-Петербург, e-mail: uraev.ga@yandex.ru

Эксперименты проводились в вегетационных условиях по изучению влияния ростостимулирующих растений ризобактерий (PGPR) (Вариоворакс, Мизорин, Флавобактерин) в качестве биоудобрения на обработку горчицы белой сорта Рапсодия и редьки масличной сорта Радуга, выращенных при нормальных условиях и почвенной засухи. На протяжении всего вегетационного периода изучались основные морфофизиологические показатели данных растений. В условиях обеспечения нормального увлажнения препараты на основе ассоциативных ризобактерий увеличивают продуктивность данных культур. Недостаток воды в почве нарушает водный статус растений, в результате происходит снижение общей оводненности растительного организма. По этой причине растения, характеризующиеся более высоким содержанием воды и стабильным водным режимом, отличаются сравнительно более высокими показателями продуктивности. Стабилизация основных физиологических процессов горчицы и редьки, снижение нарушений функциональной активности их водного статуса, наряду с накоплением основных элементов минерального питания, стабилизацией других физиологических процессов, способствует сохранению продуктивности и качества зеленой массы, а также урожая семян в условиях недостатка почвенной влаги. В результате обработки экспериментальных данных было отмечено также, что у инокулированных растений отмечена более высокая водоудерживающая способность. Наилучшие результаты получены при использовании бактериальных препаратов: Вариоворакс (Variovorax paradoxus, strain 5C-2) и Мизорина (Arthrobacter mysorens, штамм 7). Проведена оценка экономического эффекта в условиях нормального увлажнения и при дефиците влаги в почве. Проведенная оценка экономического эффекта показывает, что при инокуляции растений повышается как урожайность, так и уровень доходов сельскохозяйственных предприятий от реализации семян.

Ключевые слова: инокуляция, продуктивность, минеральное питание, интродукция, ризобактерии, способствующие росту растений (PGPR), засуха, водный стресс, ассоциативные ризобактерии, экономический эффект

\title{
THE EFFECT OF PLANT GROWTH-PROMOTING ASSOCIATIVE RHIZOBACTERIA ON SOME PLANTS OF BRASSICACEAE IN CONDITIONS OF NORMAL MOISTURE AND SOIL DROUGHT
}

\author{
${ }^{1}$ Lebedev V.N., ${ }^{1}$ Vorobeykov G.A., ${ }^{2}$ Uraev G.A. \\ ${ }^{1}$ Herzen State Pedagogical University of Russia, Saint Petersburg, e-mail: antares-80@yandex.ru; \\ ${ }^{2}$ Emperor Alexander I St. Petersburg State Transport University, Sankt-Petersburg, \\ e-mail: uraev.ga@yandex.ru
}

The problem of safe agricultural products production and use of biological methods in order to increase crops productivity are examined in the article. Experiments were carried out in vegetative conditions to study the effect of growth-stimulating plants of rhizobacteria (PHPR) (Variovorax, Mizorin, Flavobacterin) as a biofertilizer on the treatment of white mustard var. Rhapsody (k-4278) and oilseed radish var. Rainbow (k-8), grown under normal conditions and soil drought. In the conditions of normal humidifying bacterial preparations increase efficiency of the given cultures. At a short-term soil drought processing of seeds rhizobacterias promotes smaller infringement of water mode, an increase in the content of the main elements of mineral nutrition and stabilization of other physiological processes that leads to preservation of the general and seed efficiency of the given plants. Therefore, plants with higher water content, have higher resistance to the effects of drought and are characterized by better productivity. As a result of processing the experimental data, it was also noted that inoculated plants had a higher water-holding capacity. The stabilization of the main physiological processes of mustard and radish, the reduction of violations of the metabolic water status, along with the accumulation of the main elements of mineral nutrition, contributes to the preservation of the productivity and quality of the biomass, and increased seed's yield in conditions of soil drought. The best results are received when using the following bacterial preparations: Variovorax (Variovorax paradoxus, strain 5C-2) and Mizorin (Arthrobacter mysorens, strain 7).

Keywords: inoculation, germinating capacity, productivity, mineral nutrition, stimulation of growth, introduce, Plant Growth-Promoting Rhizobacteria (PGPR), drought, water stress, associative rhizobacteria, economic effect

Одной из основных задач современного земледелия является замена химических соединений, способных загрязнить продукцию и окружающую среду токсическими веществами, на более экологически безопас- ные способы повышения продуктивности сельскохозяйственных культур. Усиление деятельности азотфиксирующих организмов является одним из таких безвредных способов [1-3]. В наше время особое вни- 
мание уделяется применению ассоциативных штаммов ризобактерий (plant-growthpromoting rhizobacteria - PGPR), которые способствуют повышению продуктивности при снижении химизации земледелия, а также положительно влияют на экономическую эффективность сельскохозяйственного предприятия. Микроорганизмы, создав тесную связь с растением, усиливают азотфиксацию на корнях, стимулируют выработку растениями фитогормонов, улучшают минеральное питание, повышают устойчивость растений к таким неблагоприятным условиям, как засуха [3-5].

Засуха - природный фактор, часто воздействующий на ростовые процессы растений и снижающий их продуктивность. Действие недостатка почвенной влаги приносит серьезный экономический ущерб, так как нередко приводит к критическому падению урожая. Для формирования будущего урожая особенно опасна засуха, приходящаяся в период бутонизации и цветения культур [6]. В данный период онтогенеза, который является критическим к недостатку почвенной воды, происходит снижение целого комплекса биохимических и физиологических процессов, что делает растительный организм наиболее чувствительным к стрессу [7].

В наше время особо актуально проводить исследования по влиянию ризобактерий на рост и развитие растений в связи с их благоприятным влиянием на урожай. Также большое значение имеет проведение исследований в области влияния ризосферных микроорганизмов на продуктивность культур при неблагоприятных факторах, в частности при засухе [8].

Цель нашей работы заключалась в определении эффективности влияния штаммов ассоциативных ризобактерий на физиологические процессы и сохранение продуктивности горчицы белой и редьки масличной белой в условиях нормального увлажнения и почвенной засухи в критический период.

\section{Материалы и методы исследования}

Исследование проведено на двух видах однолетних крестоцветных культур: горчице белой (Sinapis alba L.), сорт Рапсодия, (к-4278) и редьке масличной (Raphanus sativus L. var. oleifera Metzg.), сорт Радуга (к-8). Сортовые семена капустных растений из ВНИИ растениеводства им. Н.И. Вавилова.

Согласно рекомендациям [9], в процессе посева была проведена инокуляция семян такими бактериальными препарата- ми, как Вариоворакс (Variovorax paradoxus, штамм 5C-2), Мизорин (Arthrobacter mysorens, штамм 7) и Флавобактерин (Flavobacterium sp. штамм 30). Все использованные в процессе работы штаммы прошли предварительный скрининг и были отобраны как самые эффективные. Бактериальные препараты были созданы на основе ассоциативных азотфиксирующих штаммов и предоставлены лабораторией экологии симбиотических и ассоциативных ризобактерий ВНИИСХМ.

Растения выращивались в вегетационных опытах по стандартной методике [9] на территории агробиостанции университета в Ленинградской области. Опыты проводились на супесчаной дерново-слабоподзолистой почве со слабокислой реакцией среды и средней обеспеченностью доступными формами фосфора и калия, а также средним содержанием гумуса (1,5-1,8\%). В каждый вегетационный сосуд для создания более высокоэффективной системы «растение - бактерия» до посева семян вносилось комплексное минеральное удобрение азофоска из расчета $\mathrm{N}_{0,1} \mathrm{P}_{0,1} \mathrm{~K}_{0,1}$ д.в. на каждый кг почвы [9; 10].

В условиях вегетационных опытов растения выращивали при 70\% влажности почвы от полной влагоемкости (нормальные условия). Для части растений после вступления их в критический период (фазу бутонизации) создавалась кратковременная почвенная засуха. На протяжении десяти дней влажность почвы не превышала 30 \%, а после была повышена до нормальных условий увлажнения и сохранялась на таком уровне до окончания вегетационного периода.

Все морфометрические параметры измерялись в соответствии с фазами развития растений, а из физиологических процессов изучались показатели, рекомендованные как наиболее надежные критерии уровня засухоустойчивости растений $[11 ; 12]$. Показатели водного режима (общая оводненность надземных органов, водоудерживающая способность) изучались после завершения периода засухи [10]. Определение основных элементов минерального питания (азота, фосфора и калия) проводили стандартным методом мокрого озоления сухой массы растений в лаборатории ВНИИСХМ. Оценка семенной продуктивности учитывалась в фазу полной спелости в конце вегетации. Обработка результатов проводилась статистическим методом дисперсионного анализа с использованием табличного процесcopa Microsoft Excel. 
Анализ экономического эффекта проводился при помощи оценки абсолютного изменения дохода от реализации семян по отношению к контролю. Более подробно этот подход оценивания экономического эффекта был нами рассмотрен в статье [13].

\section{Результаты исследования и их обсуждение}

В результате вегетационного опыта установлено негативное влияние недостатка почвенной влаги на такой интегральный ростовой показатель, как высота растений. Анализ полученных данных свидетельствует, что предпосевная обработка семян ассоциативными штаммами способна снизить тормозящий эффект на ростовые процессы, которые связаны с влиянием неблагоприятных факторов окружающей среды (табл. 1). Растения в опытных вариантах с применением инокуляции, подвергнутые кратковременной засухе, к фазе активного цветения были существенно выше необработанных на 23-27\% (горчица белая) и 2-14\% (редька масличная). Наибольший эффект был отмечен при использовании ризобактерий Variovorax paradoxus (127\% у горчицы и $114 \%$ у редьки) и Arthrobacter mysorens (123\% у горчицы и $104 \%$ у редьки).

Засуха способна влиять на изменение оводненности тканей растительного организма в сторону ее уменьшения из-за нару- шения способностей поглощать воду и сохранять в клетках. Способность растений не изменять свою оводненность представляет собой адаптационный механизм к дефициту почвенной влаги. Однако иногда при засухе механизмы поддержки водоудерживающих сил начинают отказывать и общее содержание воды в клетках падает. Возникающий в засушливый период дефицит влаги в почве может приводить к необратимым последствиям ухудшения водного статуса. Следовательно, растения, содержащие большее количество воды, являются наиболее засухоустойчивыми и потенциально более продуктивными в отношении накопления сухого вещества и урожайности семян.

При нормальном увлажнении растения горчицы белой и редьки масличной в фазу начала цветения имели среднюю оводненность $83-86 \%$ и 73-85\% соответственно (табл. 2). Почвенная засуха снижала данный показатель водного режима до 65-71\% в опытах с горчицей и 44-64\% у редьки. Предпосевная инокуляция бактериальными препаратами способствовала стабилизации водного режима путем поддержания общего содержания воды в надземных органах на постоянном уровне у исследованных нами культур, несмотря на то что в конце периода засухи растения опытных вариантов испытывали значительный водный дефицит.

Влияние инокуляции семян ассоциативными ризобактериями

Таблица 1 на высоту растений горчицы белой и редьки масличной, см

\begin{tabular}{|l|c|c|c|c|c|c|}
\hline \multirow{2}{*}{ Вариант } & \multicolumn{3}{|c|}{ Горчица белая } & \multicolumn{3}{c|}{ Редька масличная } \\
\cline { 2 - 7 } & НУ* & П3** & ПЗ/НУ*** & НУ & П3 & П3/НУ \\
\hline Контроль & 43,5 & 32,0 & 0,74 & 76,0 & 62,5 & 0,82 \\
\hline Вариоворакс & 46,6 & 40,6 & 0,87 & 82,0 & 71,0 & 0,87 \\
\hline Мизорин & 49,0 & 39,3 & 0,80 & 77,4 & 65,0 & 0,84 \\
\hline Флавобактерин & 53,4 & 40,2 & 0,75 & 76,8 & 63,8 & 0,83 \\
\hline HСР $_{0,05}$ & 3,57 & 3,1 & - & 0,7 & 10,4 & - \\
\hline
\end{tabular}

П р и м е ч а н и е : НУ* - нормальное водоснабжение; ПЗ** - почвенная засуха; ПЗ/НУ*** - коэффициент стабильности развития растений.

Таблица 2

Содержание воды в растениях в зависимости от штамма ризобактерий (фаза цветения), \%

\begin{tabular}{|l|c|c|c|c|c|c|}
\hline \multirow{2}{*}{ Вариант } & \multicolumn{3}{|c|}{ Горчица белая } & \multicolumn{3}{c|}{ Редька масличная } \\
\cline { 2 - 7 } & НУ & П3 & ПЗ/НУ & НУ & П3 & П3/НУ \\
\hline Контроль & 83 & 65 & 0,78 & 73 & 44 & 0,60 \\
\hline Вариоворакс & 85 & 69 & 0,81 & 85 & 64 & 0,76 \\
\hline Мизорин & 86 & 71 & 0,83 & 81 & 61 & 0,75 \\
\hline Флавобактерин & 85 & 71 & 0,84 & 78 & 61 & 0,79 \\
\hline НСР $_{0,05}$ & 1,4 & 3,2 & - & 2,8 & 1,9 & - \\
\hline
\end{tabular}


Кроме того, нами также было отмечено, что у инокулированных растений редьки масличной имеется более высокая водоудерживающая способность, особенно при обработке штаммом Вариоворокса. Однако наибольшая водоудерживающая способность у горчицы белой была характерна для растений, инокулированных при посеве Мизорином и Флавобактерином.

Известно [4; 8; 14], что одним из способов, повышающих засухоустойчивость растений, является улучшение их минерального питания в результате взаимодействии c ассоциативными ризобактериями. Это особенно актуально в связи с тем, что засуха, по нашим данным, негативно отражается на поступлении основных минеральных элементов (табл. 3).

Использование биопрепаратов при нормальном условии увлажнения почвы способствовало повышению содержания азота в сухом веществе с 1,70 до 2,29\% (горчица) и с 2,16 до 2,76\% (редька). Кроме того, наблюдалось также возрастание в надземных органах концентрации фосфора до $1,30-1,42 \%$ и до $0,76-0,94 \%$ соответственно. При этом контрольные варианты (без инокуляции) отличались минимальными значениями этих показателей. Однако растения инокулированных вариантов по- сле перенесения почвенной засухи снижали содержание азота, фосфора и калия менее значительно.

Анализ продуктивности семян показал, что предпосевная обработка культур ассоциативными штаммами увеличивает количество семян (табл. 4). Следует отметить, что после переживания недостатка влаги в почве опытные варианты с применением биопрепаратов, по сравнению с контролем, характеризовались более высокими показателями семенной продуктивности. В отсутствии засухи масса семян у редьки возрастала на 20\% в варианте с Вариовораксом, а у горчицы на $80 \%$ в опыте с Мизорином, относительно контроля. Инокулированные растения при почвенной засухе отличались большей массой семян, чем контрольные, на 75-88 \% (горчица) и на 20-49\% (редька).

Таким образом, урожай семян горчицы белой и редьки масличной заметно изменяется в зависимости от обеспеченности почвы доступной влагой и инокуляции семян бактериальными препаратами. При этом у данных культур в опытных вариантах, где проводилась предпосевная инокуляция ассоциативными ризобактериями, отмечалась более выраженная семенная продуктивность, которая лучше сохранялась при действии почвенной засухи.

Влияние ризобактерий на содержание азота, фосфора и калия

Таблица 3 в надземных органах растений, \%

\begin{tabular}{|c|c|c|c|c|c|c|c|c|c|c|c|c|}
\hline \multirow[t]{3}{*}{ Вариант } & \multicolumn{6}{|c|}{ Горчица белая } & \multicolumn{6}{|c|}{ Редька масличная } \\
\hline & \multicolumn{3}{|c|}{ НУ } & \multicolumn{3}{|c|}{$\Pi 3$} & \multicolumn{3}{|c|}{ HУ } & \multicolumn{3}{|c|}{$\Pi 3$} \\
\hline & $\mathrm{N}$ & $\mathrm{P}_{2} \mathrm{O}_{5}$ & $\mathrm{~K}_{2} \mathrm{O}$ & $\mathrm{N}$ & $\mathrm{P}_{2} \mathrm{O}_{5}$ & $\mathrm{~K}_{2} \mathrm{O}$ & $\mathrm{N}$ & $\mathrm{P}_{2} \mathrm{O}_{5}$ & $\mathrm{~K}_{2} \mathrm{O}$ & $\mathrm{N}$ & $\mathrm{P}_{2} \mathrm{O}_{5}$ & $\mathrm{~K}_{2} \mathrm{O}$ \\
\hline Контроль & 1,70 & 1,00 & 1,60 & 1,29 & 0,81 & 1,20 & 2,29 & 0,43 & 2,01 & 1,95 & 0,34 & 2,14 \\
\hline Вариоворакс & 2,16 & 1,42 & 2,30 & 2,09 & 1,22 & 2,05 & 2,29 & 0,94 & 2,72 & 2,20 & 0,91 & 3,25 \\
\hline Мизорин & 2,02 & 1,42 & 2,31 & 1,86 & 1,21 & 1,99 & 2,76 & 0,92 & 2,35 & 2,04 & 0,75 & 2,95 \\
\hline Флавобактерин & 2,10 & 1,30 & 2,63 & 1,70 & 1,04 & 2,21 & 2,41 & 0,76 & 2,25 & 2,00 & 0,59 & 3,00 \\
\hline $\mathrm{HCP}_{0,05}$ & 0,05 & 0,04 & 0,04 & 0,05 & 0,04 & 0,04 & 0,10 & 0,30 & 0,22 & 0,04 & 0,22 & 0,32 \\
\hline
\end{tabular}

Таблица 4

Урожай семян инокулированных растений при нормальном водоснабжении и после почвенной засухи (на 1 сосуд)

\begin{tabular}{|l|c|c|c|c|c|c|c|c|}
\hline \multirow{3}{*}{ Вариант } & \multicolumn{4}{|c|}{ Горчица белая } & \multicolumn{4}{c|}{ Редька масличная } \\
\cline { 2 - 10 } & \multicolumn{2}{|c|}{ НУ } & \multicolumn{2}{c|}{ ПЗ } & \multicolumn{3}{c|}{ НУ } & \multicolumn{2}{c|}{ ПЗ } \\
\cline { 2 - 10 } & $1^{*}$ & $2 *$ & 1 & 2 & 1 & 2 & 1 & 2 \\
\hline Контроль & 492 & 3,0 & 282 & 0,8 & 554 & 3,14 & 372 & 1,67 \\
\hline Вариоворакс & 752 & 4,2 & 500 & 1,4 & 580 & 3,77 & 516 & 2,49 \\
\hline Мизорин & 888 & 5,4 & 524 & 1,5 & 556 & 3,72 & 489 & 2,31 \\
\hline Флавобактерин & 832 & 5,0 & 488 & 1,5 & 602 & 3,45 & 452 & 2,00 \\
\hline НСР $_{0,05}$ & 36,4 & 0,4 & 22,4 & 0,3 & 49,0 & 0,30 & 50,8 & 0,32 \\
\hline
\end{tabular}

П р и м е ч а н и е : $1 *$ - количество семян (шт./сосуд), $2 * *-$ масса семян (г/сосуд). 
Рассмотренные выше факторы влияют и на экономический эффект сельскохозяйственного предприятия (табл. 5).

Таблица 5

Доход от реализации семян растений при нормальном водообеспечении и после почвенной засухи, руб. за 100 г семян

\begin{tabular}{|l|c|c|c|c|}
\hline \multirow{2}{*}{ Вариант } & \multicolumn{2}{|c|}{$\begin{array}{c}\text { Горчица } \\
\text { белая }\end{array}$} & \multicolumn{2}{c|}{$\begin{array}{c}\text { Редька } \\
\text { масличная }\end{array}$} \\
\cline { 2 - 5 } & НУ & П3 & НУ & П3 \\
\hline Контроль & 207 & 32 & 452 & 162 \\
\hline Вариоворакс & 442 & 98 & 569 & 334 \\
\hline Мизорин & 671 & 110 & 538 & 294 \\
\hline Флавобактерин & 582 & 102 & 541 & 235 \\
\hline
\end{tabular}

Доходы сельскохозяйственных предприятий от реализации семян горчицы белой и редьки масличной находятся в зависимости от обеспеченности почвы водой и инокуляции семян бактериальными препаратами. При нормальном водообеспечении инокуляция семян горчицы белой может привести к значительному увеличению дохода от реализации семян. По нашей оценке, увеличение доходов находилось в пределах 2,1-3,3 раза у горчицы и в пределах 1,21,3 раза у редьки. Аналогичное влияние наблюдается и в условиях почвенной засухи: увеличение дохода в интервале $3,1-3,5$ раза (горчица) и 1,5-2,1 раза (редька).

\section{Выводы}

Вегетационные опыты с горчицей белой и редькой, семена которых были инокулированы ассоциативными ризобактериальными штаммами, в условиях почвенной засухи характеризуются меньшими нарушениями роста в высоту, лучшей перманентной оводненностью растительных тканей и относительно высокой водоудерживающей способностью. Стабилизация основных физиологических процессов горчицы и редьки, снижение нарушений функциональной активности их водного статуса, наряду с накоплением основных элементов минерального питания, способствует сохранению продуктивности и качества зеленой массы, а также урожая семян в условиях недостатка почвенной влаги.

Наиболее эффективной по сумме исследованных показателей оказалась предпосевная инокуляция семян горчицы белой (Sinapis alba L.) сорта Рапсодия и редьки масличной (Raphanus sativus L. var. oleifera Metzg.) сорта Радуга Варивораксом
(Variovorax paradoxus, штамм 5С-2) и Мизорином (Arthrobacter mysorens, штамм 7). B наших опытах данные препараты на основе ассоциативных ризобактериальных штаммов не только стимулировали морфофизиологические процессы и продуктивность в условиях нормального увлажнения, но и способствовали снижению негативного влияния стрессовых условий засухи на рассмотренные параметры.

Кроме того, проведенная оценка экономического эффекта показывает, что растения, семена которых были инокулированы ассоциативными ризобактериальными штаммами, позволяют увеличить уровень доходов сельскохозяйственных предприятий. Однако следует отметить, что при условии предпосевной обработки семян биопрепаратами недостаток почвенной влаги по-разному влияет на уровень экономического дохода от реализации семян выбранных капустных растений.

\section{Список литературы / References}

1. Артамонова М.Н., Потатуркина-Нестерова Н.И., Беззубенкова О.Е. Роль бактериальных симбионтов в растительно-микробных ассоциациях // Вестник Башкирского университета. 2014. №1(19). С. 81-84.

Artamonova M.N., Potaturkina-Nesterova N.I., Bezzubenkova O.E. The role of bacterial symbionts in plant-microbial associations // Vestnik Bashkirskogo universiteta. 2014. № 1 (19). P. 81-84 (in Russian).

2. Лебедев В.Н. Ассоциативные штаммы бактерий как современный элемент экологизации выращивания капустных растений // Известия РГПУ им. А.И. Герцена. 2014. № 168. C. 49-53.

Lebedev V.N. Associative bacterial strains as a modern element of greening the cultivation of cabbage plants // Izvestiya RGPU im. A.I. Gercena. 2014. № 168. P. 49-53 (in Russian).

3. Лебедев В.Н., Ураев Г.А. Оценка эффективности инокуляции семян четырех видов горчиц ассоциативными азотфиксирующими штаммами ризобактерий // Фундаментальные исследования. 2015. № 2-25. С. 5594-5598.

Lebedev V.N., Uraev G.A. Evaluation of the effectiveness of inoculation of seeds of four mustard species by associative nitrogen-fixing strains of rhizobacteria // Fundamental'nye issledovaniya. 2015. № 2-25. P. 5594-5598 (in Russian).

4. Белимов А.А. Взаимодействие ассоциативных бактерий и растений в зависимости от биотических и абиотических факторов: автореф. дис. ... докт. биол. наук. СанктПетербург, 2008. 46 с.

Belimov A.A. Interaction of associative bacteria and plants depending on biotic and abiotic factors: avtoref. dis. ... dokt. biol. nauk, Sankt-Peterburg, 2008. 46 p. (in Russian).

5. Shrivastava U.P. Characterization of diazotrophic rhizobacteria under various conditions. International Journal of Applied Sciences and Biotechnology. 2013. Vol. 1(3). P. 110-117.

6. Воробейков Г.А., Бредихин В.Н., Лебедев В.Н., Юргина В.С. Биология критического периода растений в условиях нарушения влажности почвы // Известия РГПУ им. А.И. Герцена. 2015. № 173. С. 49-53.

Vorobejkov G.A., Bredihin V.N., Lebedev V.N., Yurgina V.S. Biology of the critical period of plants under conditions of soil moisture disturbance // Izvestiya RGPU im. A.I. Gercena. 2015. № 173. P. 49-53 (in Russian).

7. Штерншис М.В. Тенденции развития биотехнологии микробных средств защиты растений в России // Вестник 
Томского государственного университета. Биология. 2012 № 2 (18). C. 92-100.

Shternshis M.V. Trends in the development of biotechnology of microbial plant protection products in Russia // Vestnik Tomskogo gosudarstvennogo universiteta. Biologiya. 2012. № 2 (18). P. 92-100 (in Russian).

8. Юргина В.С. Морфофизиологические особенности и продуктивность редьки масличной (Raphanus sativus L. var. oleifera Metzg) при инокуляции семян ассоциативными ризобактериями в условиях нормального увлажнения и почвенной засухи: автореф. дис. ... канд. биол. наук. СанктПетербург, 2011. 18 c.

Yurgina V.S. Morphophysiological features and productivity of oilseed radish (Raphanus sativus L. var. oleifera Metzg) under seed inoculation by associative rhizobacteria under conditions of normal moisture and soil drought: avtoref. dis. ... kand. biol. nauk. Sankt-Peterburg, 2011. 18 p. (in Russian).

9. Тихонович И.А., Кожемяков А.П., Чеботарь В.К., Круглов Ю.В., Кандыбин Н.В., Лаптев Г.Ю. Биопрепараты в сельском хозяйстве: методология и практика применения микроорганизмов в растениеводстве и кормопроизводстве. М.: Россельхозакадемия, 2005. 154 с.

Tihonovich I.A., Kozhemyakov A.P., Chebotar' V.K. Kruglov Yu.V., Kandybin N.V., Laptev G.Yu. Biological products in agriculture: methodology and practice of application of microorganisms in crop production and feed production. M.: Rossel'hozakademiya, 2005. 154 p. (in Russian).

10. Третьяков Н.Н., Карнаухова Т.В., Паничкин Л.А., Пильщикова Н.В., Кошкин Е.И., Крастина Е.Е., Земский В.Г. Можаева Л.В., Петров-Спиридонов А.Е., Геллерман Я.М., Кондратьев М.Н., Калинкевич М.И., Крастина Е.Е., Каменская К.И. Практикум по физиологии растений. М.: Агропромиздат, 1990. $271 \mathrm{c}$.
Tret'yakov N.N., Karnauhova T.V., Panichkin L.A., Pil'shchikova N.V., Koshkin Ye.I., Krastina Ye.Ye., Zemskiy V.G., Mozhayeva L.V., Petrov-Spiridonov A.Ye., Gellerman YA.M., Kondrat'yev M.N., Kalinkevich M.I., Krastina Ye. Ye., Kamenskaya K.I. Workshop on plant physiology. M.: Agropromizdat, 1990. 271 p. (in Russian).

11. Гунес А., Инал А., Адак М.С., Багци Е.Г., Цицек Н., Ераслан Ф. Влияние засухи до и после зацветания растений нута на ряд физиологических параметров - возможных критериев засухоустойчивости // Физиология растений. 2008. T. 55. № 1. C. 64-72.

Gunes A., Inal A., Adak M.S., Bagci E.G., Cicek N., Eraslan F. The effect of drought before and after chickpea flowering on a number of physiological parameters-possible criteria for drought resistance // Fiziologiya rastenij. 2008. Vol. 55. № 1. P. 64-72 (in Russian).

12. Fatih C., Murat E., Mehmet S., Arzu C. The Role of Beneficial Microorganisms in the Protection of Plants Growing in Natural Landscape Areas. Siirt. 2017. P. 427-442.

13. Лебедев В.Н., Воробейков Г.А., Ураев Г.А. Повышение продуктивности растений семейства капустных (Brassicaceae Burnett.) при инокуляции семян бактериальными препаратами на основе ассоциативных штаммов // Успехи современного естествознания. 2017. № 5. C. 41-45.

Lebedev V.N., Vorobejkov G.A., Uraev G.A. Increasing the productivity of plants of the cabbage family (Brassicaceae Burnett.) when inoculating seeds with bacterial preparations based on associative strains // Uspekhi sovremennogo estestvoznaniya. 2017. № 5. P. 41-45 (in Russian).

14. Bhattacharyya P.N., Jha D.K. Plant growth-promoting rhizobacteria (PGPR): emergence in agriculture. World Journal of Microbiology and Biotechnology. 2012. Vol. 28 P. 1327-1350. 